\title{
有機媒体を用いたランキンサイクル による廃熱回収についで
}

\author{
大橋 智**・鈴木俊 行****
}

Waste Heat Recovery with Using Organic Fluid

By Satoru Ohashi, Toshiyuki Suzuki

\begin{abstract}
As a means of heat recovery in marine field as well as in land industrial processes, the use of waste heat boilers to generate steam which derives conventional steam turbine, in turn, drive electrical generator is wellknown technique. While, in many potential waste heat applications, the gases or liquids which function as the heat source are relatively low temperature levels. It is hardly possible to operate an efficient and simple Rankine Cycle engine using steam as the working fluid with these low heat source temperature. One of the attractive features of a Rankine Cycle with Organic working fluid is its ability to operate efficiently with low temperature heat source, which permits use of various low grade energy source have not been effectively harnessed in the past. This Organic Rankine Cycle System is based on the use of Fluorinol-85 as a working fluid. In addition to desirable thermodynamic characteristics, use of this fluid has the following primary advantages relative to steam cycle waste heat recovery system.
\end{abstract}

- Substantially higher power output

- High conversion efficiency

- Simple and compact turbine design

\section{1. まえがき}

船舶原動所にあっては, 昔からェネルギの有効利用と 省エネルギの観点から熱効率の向上に並々ならぬ努力が 払わ机てきたし，また，それなりの成果も十分あがって きた. 特に 1973 年秋のオイルショックを契機として石 油エネルギの高価格時代に突入している現在は, 努力目 標が省エネルギを指向することは当然である. 省エネル ギとは，いろいろ見方があるが，要は燃料消費量を現在 量以下に押え，付加価置を現在量あるいはそれ以上にす ることであって, この意味での熱効率の向上が要望され る.

船舶原動所にあってはディーゼルェンジンなどの単体 機器の熟効率の向上はもちろん重要であるが, これら個 々の要素の効率というよりも, むしろ原動所システム全 体としての効率向上が期待されるところであり, 主機デ ィーゼル排ガスを利用する排ガスエコノマイザとター ボ発電機は既に実用されている好例である. しかし,こ の例にあっても, 船内必要電力のみを主機械廃熱より回 収発電しているにすぎず, その回収率は低く, また, 量 的にも主機排ガスエネルギを可能な範半において全量有

* 原稿受付 昭和 52 年 5 月 10 日

** 正会員三井造船(株)開発本部(東京都中央区築地 5-6-4)

***正会員 三井造船(株)技術本部(玉野市玉 3-1-1)
効に回収しているとは言えないのが実情である．汎用デ ィーゼルェンジンに限らず，その排出温度レベルである $200^{\circ}$ Cないし 500 C の廃熱保有熱エネルギを動力へ回収 転換する作動媒体として, 従来, 慣用されている水に代 って，低沸点有機物質“フロリノール85”を使用する と, 水の場合よりも高い動力回収量が得られる.この 有機物質を使用したランキンサイクルシステム(Organic Rankine Cycle System-ORCS), フロリノール 85 の有用性拈よびディーゼルェンジン廃熱回収例について 以下述べてみたい。

\section{ORCS}

2.1 ORCSの基本サイクル フロリノール 85 （F-85）を使用する基本サイクルを図 1 に，また，その $\mathrm{T}-\mathrm{S}$ 線図を図 2 に示す. 本例では $400^{\circ} \mathrm{C}$ 程度の廃熱を利 用するものであって, 蒸気発生器で過熱領域まで加熱さ れた F-85蒸気(1)はタービンで膨張し外部に仕事 $W_{T}$ を与 えた後の(2)の状態でタービンを出る. 蒸気を用いたター ビンの出口状態は一般に湿り領域にあるのが普通である が， F-85 の飽和蒸気線は $T-S$ 線困上で直立している ため湿り域にはいらず，タービン出口でもまだ過熱状態 である. (2)の状態の過熱蒸気は再生器に送られてここで 蒸気発生器に給液される液体を予熱した後(3で少し過熱 状態で凝縮器にはいり (4)〜 (5)間で疑縮する. 液は給液ポ 


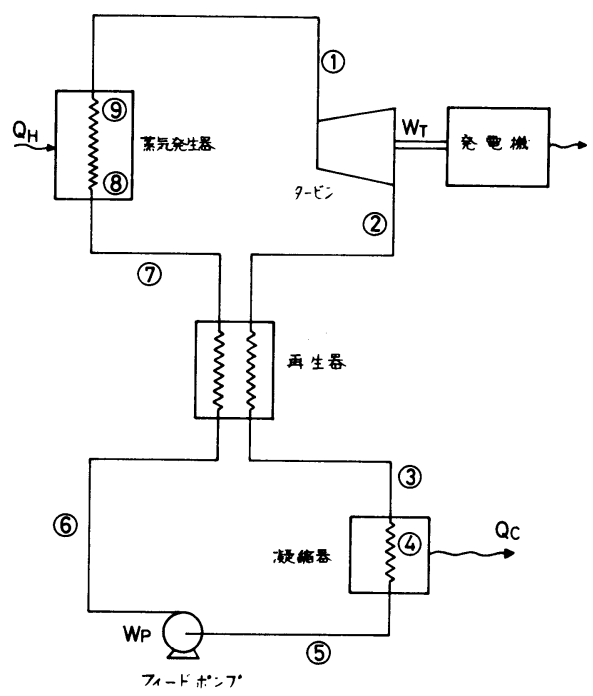

図 1 有機媒体ランキンサイクルの ブロックダイヤグラム

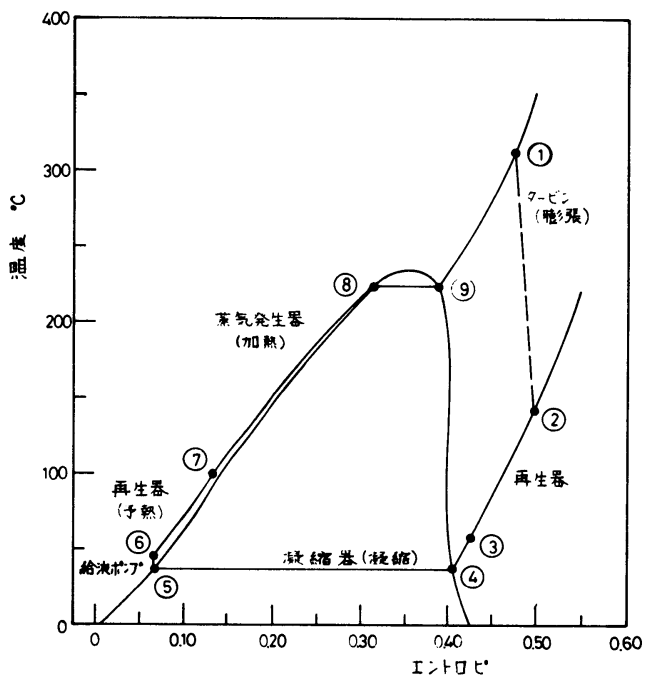

図 2 フロリノール 85 を使用した ランキンサイクル $\mathrm{T}-\mathrm{S}$ 線図

ンプで所定の圧力まで加圧された後, 再生器(6) (7)で予 熱され蒸気発生器に送られる. 蒸気発生器では液体は廃 熱によって加熱され, 液温上昇(7)～(8), 蒸発(8)～(9), 過 熱(9)〜(1)で行われて密閉サイクルを完結する.

2.2 複合システムとその効率 ディーゼルェン ジンの排出熱エネルギをランキンサイクルで動力に回収 転換するフローダイヤグラムを図 3 に示す. 本例では高 温である排ガスを高圧ランキンサイクルで, 低温度であ るシリンダ冷却水を低圧ランキンサイクルで動力回収す るものであって, 上記以外の廃熱は対象外として取扱う.
$Q_{R U}=[1-(f 1+f 2+f 3)]\left[Q_{H}-W_{E}\right] \quad Q_{R W}=f 3\left(Q_{H}-W_{E}\right)$

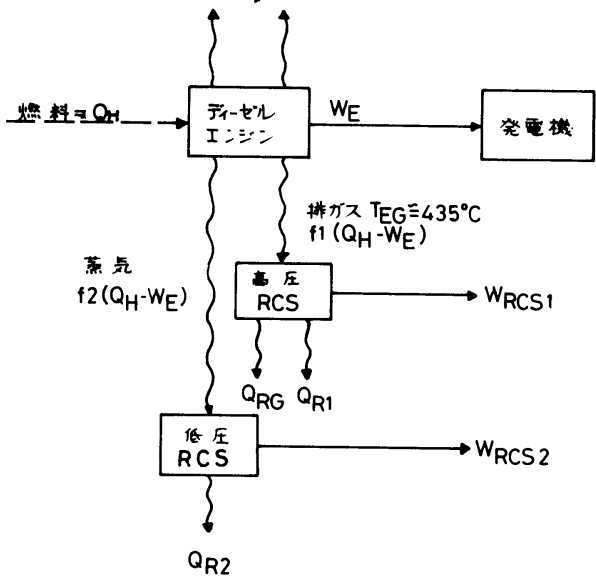

図 3 複合システムフローダイヤグラム

ここに複合システムの全効率を求めてみる.

$Q_{\mathrm{H}} \quad$ 燃料の保有熱量(低発熱量)

$W_{\mathrm{E}} \quad$ ディーゼルェンジン軸出力

$Q_{\mathrm{H}}-W_{\mathrm{E}}$ 全損失熱量

$f_{1}$ 排ガス熱損失割合

$f_{2} \quad$ シリンダ冷却水熱損失割合

$f_{3}$ 潤滑油冷却器および空気冷却器熱損失割合

$W_{\mathrm{RCS} 1}$ 高圧ランキンサイクル発生軸出力

$W_{\mathrm{RCS} 2}$ 低圧ランキンサイクル発生軸出力

$Q_{\mathrm{R} 1}$ 高圧ランキンサイクル凝縮器放熱量

$Q_{R 2} \quad$ 低圧ランキンサイクル凝縮器放熱量

$Q_{\mathrm{RW}}$ 潤滑油冷却器, 空気冷却器冷却水放熱量

$Q_{\mathrm{RU}}$ 輻射その他の放熱量

$Q_{R G}$ 高圧蒸気発生器よりの排出ガス保有熱量

$\eta_{\mathrm{B}}$ 高圧蒸気発生器(ボイラ) 効率

$=1-\frac{Q_{\mathrm{RG}}}{f_{1}\left(Q_{\mathrm{H}}-W_{\mathrm{E}}\right)}$

ディーゼルェンジン自体の熱効率 $\eta_{\mathrm{E}}=\frac{W_{\mathrm{E}}}{Q_{\mathrm{H}}}$

$W_{\mathrm{RCS} 1}=\left(\eta_{\mathrm{RCS} 1}\right)\left(\eta_{\mathrm{B}}\right)\left(f_{1}\right)\left(Q_{\mathrm{H}}-W_{\mathrm{E}}\right)$

$W_{\mathrm{RCS} 2}=\left(\eta_{\mathrm{RCS} 2}\right)\left(f_{2}\right)\left(Q_{\mathrm{H}}-W_{\mathrm{E}}\right)$

$\left(\eta_{\mathrm{RCS} 1}\right),\left(\eta_{\mathrm{RCS} 2}\right)$ はそれぞれ高・低圧ランキンサイクル のサイクル効率を示す. 複合システムの全効率を $\eta_{p}$ とす ると

$$
\begin{aligned}
\eta_{p} & =\frac{W_{\mathrm{E}}+W_{\mathrm{RCS} 1}+W_{\mathrm{RCS} 2}}{Q_{\mathrm{H}}} \\
& =\frac{W_{\mathrm{E}}+\eta_{\mathrm{RCS} 1} \cdot \eta_{\mathrm{B}} \cdot f_{1} \cdot\left(Q_{\mathrm{H}}-W_{\mathrm{E}}\right)+\eta_{\mathrm{RCS} 2} \cdot f_{2} \cdot\left(Q_{\mathrm{H}}-W_{\mathrm{E}}\right)}{Q_{\mathrm{H}}}
\end{aligned}
$$

あるいは

$$
\eta_{p}=\eta_{\mathrm{E}}+\left(1-\eta_{\mathrm{E}}\right) \times\left\{f_{1} \cdot \eta_{\mathrm{B}} \cdot \eta_{\mathrm{RCS} 1}+f_{2} \cdot \eta_{\mathrm{RCS} 2}\right\}
$$

12 気筒 V 形四サイクル過給機付き発電用ディーゼル エンジン $(514 \mathrm{rpm}$, 気筒当り $500 \mathrm{HP})$ を例にとると，

$T_{\mathrm{EG}}=435^{\circ} \mathrm{C}$ 


$$
\left.\begin{array}{l}
\eta_{\mathrm{E}}=0.389 \\
f_{1}=0.604 \\
f_{2}=0.124 \\
f_{3}=0.234 \\
1-\left(f_{1}+f_{2}+f_{3}\right)=0.038
\end{array}\right\} \begin{aligned}
& \text { ランキンサイクルの } \\
& \text { 対象外 }
\end{aligned}
$$

ランキンサイクルに $\mathrm{F}-85$ を使用し, 凝縮器での凝縮温 度を $32^{\circ} \mathrm{C}$ とすると

$\eta_{\mathrm{RCS} 1}=0.284$ (後述参照)

$\eta_{\mathrm{RCS} 2}=0.123$

高圧サイクル蒸気発生器より排ガス温度が $117^{\circ} \mathrm{C}$ の き

$$
\eta_{\mathrm{B}}=0.803
$$

上記数值を代入すると

$$
\begin{aligned}
\eta_{p} & =0.389+0.0842+0.0093 \\
& =0.483
\end{aligned}
$$

出力割合は次のとおりである.

$$
\begin{array}{lr}
\text { ディービルエンジン } & 80.6 \% \\
\text { 高生ORCS } & 17.5 \% \\
\text { 低任ORCS } & 1.9 \%
\end{array}
$$

$\eta_{p}=0.483$ は然料消費量を増加することなしに， 24 \%の出力増を意味するものである. 引用したエンジンは， 排ガ ス温度 $435^{\circ} \mathrm{C}$, 軸効率 $38.9 \%$ であり性能的にやや見 劣りするが, 軸効率 $40 \%$ 以上の新鋭発電用ディーゼルェ ンジンにあっては, ェンジン自体の性能が良いためORCS による出力増加割合が 15 20\%程度に減少するが，全 効率では上記の値は十分達成出来るであろう.

\section{ORCSでの回収動力}

前章に示すごとく排ガスによる高圧サイクルの動力回 収割合が大きいので，以下に排ガス廃熱回収 ORCSでの 回収動力について述べてみる.

3.1 理論最大利用可能量廃熱エネルギを動力 に変換する場合の熱効率は従来の熱力学的サイクルの考 え方と異なる。従来のサイクルは，たとえば, カルノー サイクルのごとく一定温度の高温源と低温源とを考えて いたのであるが，熱源温度は放熱に従って低下するので， 一定温度として考えることは出来ない. 図 4 において, 熱源が蒸気発生器に温度 $T_{1}$ ではいり $T_{2}$ で出るとし, その 間のすべての熱源温度と大気温度 $T_{0}$ との温度差間で働く 微少カルノーサイクルを連続的に動かすとする.

それぞれの可逆サイクルでの効率は

$$
\begin{gathered}
\eta_{i}=\frac{d W_{i}}{d Q_{i}}=\frac{T_{i}-T_{0}}{T_{i}} \\
d Q_{i}=-C_{p} d T_{i} \text { であるので } \\
d W_{i}=\left(-C_{p}\right)\left\{\left(1-\frac{T_{0}}{T_{i}}\right) \cdot d T_{i}\right\}
\end{gathered}
$$

熱源媒体の比熱を一定として温度 $T_{1} \sim T_{2}$ で積分すると この間での可逆仕事は

$$
\left(W_{\mathrm{Rev}}\right)=\int_{1}^{2} d W_{i}=C_{p}\left\{\left(T_{1}-T_{2}\right)-T_{0} \ln \frac{T_{1}}{T_{2}}\right\}
$$

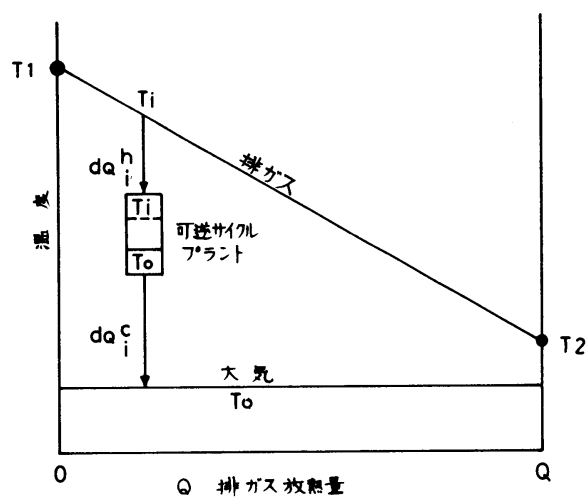

図 4 微少連続カルノーサイクルによる廃熱の動力化

上記可逆仕事と, 熱源が大気温度 $T_{0}$ まで温度降下すると きの放熱量との比を $\eta_{\mathrm{Rev}}$ とおくと

$$
\begin{gathered}
\eta_{\mathrm{Rev}}=\frac{T_{1}-T_{2}}{T_{1}-T_{0}}-\frac{T_{0}}{T_{1}-T_{0}} \ln \frac{T_{1}}{T_{2}} \\
T_{2}=T_{0} \text { のとき } \\
\left(\eta_{\text {Rev }}\right)_{\text {max }}=1-\frac{T_{0}}{T_{1}-T_{0}} \ln \frac{T_{1}}{T_{0}}
\end{gathered}
$$

排ガス温度を $435^{\circ} \mathrm{C}\left(T_{1}=708^{\circ} \mathrm{K}\right)$, 放熱後の温度 117 ${ }^{\circ} \mathrm{C}\left(T_{2}=390^{\circ} \mathrm{K}\right)$, 大気温度 $32^{\circ} \mathrm{C}\left(T_{0}=305^{\circ} \mathrm{K}\right)$ とすると

$$
\begin{aligned}
& \eta_{\text {カル }}=1-\frac{T_{0}}{T_{1}}=0.569 \text { (最大温度差のとき) } \\
& \eta_{\text {Rev }}=0.338 \\
& \left(\eta_{\text {Rev }}\right)_{\text {max }}=0.363 \\
& \frac{\left(\eta_{\text {Rev }}\right)_{\text {max }}}{\eta_{\text {カルノ- }}}=0.638 \\
& \frac{\eta_{\text {Rev }}}{\left(\eta_{\text {Rev }}\right)_{\text {max }}}=0.931
\end{aligned}
$$

本例では理論最大熱効率は初期温度のカルノーサイク ル効率の約 $64 \%$ 程度であることを示す.

\section{2 実際のサイクル 3.1にあっては熱源, す} なわち, 排ガスそのものの温度を使って理論効率を算出 したが，実際の装置では熱源より受熱する作動媒体がサ イクルを構成し，また仕事を行う．廃熱回収にあっては 一般に熱源温度が低いので蒸気発生器等の材料が高温を 理由に問題となることはないので, 従って, 作動媒体の サイクル条件を上記 3.1 の状態に可逆的に近づけること が利用可能量を増大することとなる. このことは，ラン キンサイクルにあっては, タービンおよび給液ポンプの 効率等の内部可逆性を大きくすると同時に, 熱交換器で の外部可逆性を大きくすることを意味するものである.

すなわち, 図 5 のごとく, (1) 蒸気発生器で媒体温度を 熱源温度に近づける, (2) 凝縮器では大気温度 (冷却水 温度)近くで凝縮を行わせしめることである.これら外 部可逆性を大きくすることは熱交換器設計時の温度差を 小さくすることでもあるので装置の価格増に指向するが, それとは別に使用する媒体の熱力学的性質と可逆性との 


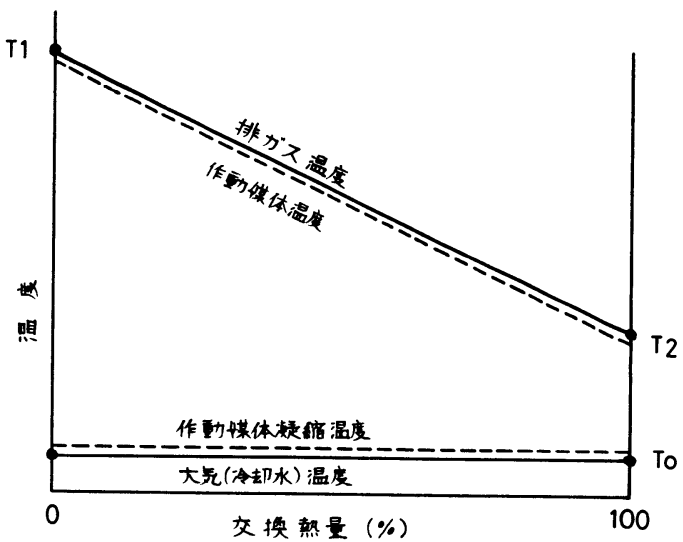

$\left(W_{\mathrm{Rev}}\right)_{T_{1} \rightarrow T_{2}}=C_{p, \text { gas }}\left\{\left(T_{1}-T_{2}\right)-T_{0} \ln \frac{T_{1}}{T_{2}}\right\}$

図 5 理想廃熱回収状態における作動媒体温度

関連を論ずる必要がある.

\section{4. フロリノール 85}

廃熱回収は言うまでもなく廃熱源の保有する熱ェネル ギを最大限に汲み上げることであり，かつ，同時にその 回収した熱エネルギを高効率で動力に転換することが要 求される. この観点で作動媒体を眺めてみる.

4.1 作動媒体としての水熱エネルギを動力に 転換するには蒸気を媒体とするランキンサイクルが昔よ り多用されてきたし, 今後ともこの方式は続くであろう.

しかし, 水は高温熱源たとえば重油燃焼ボイラの燃焼 室内温度の $1,500{ }^{\circ} \mathrm{C}$ を越えるような場合には, 優れた媒 体であるが，ここで話題にしている廃熱の温度レべルに あって熱力学的には優れた媒体ではない. 廃熱温度レへ ルで水を媒体とするランキンサイクルにあっては蒸気発 生器で次の不都合がある.

（1）蒸発潜熱が大きいため媒体の受熱線が熱源温度に 近隣し得ない.すなわち, 図 6 に示すごとく理想的 な無段階ランキンサイクルから遠のいていくことに なる.

（2）沸点が高いため, 中.低温度熱源では十分なる圧 力(温度)蒸気が得られない.

これらは, 重油燃焼ボイラにあっては, 問題ではなく, 蒸気は過熱器材料が許容する範囲において高温, 高生に 指向できる. 廃熱であっても蒸気発生器内での蒸発温度 を少しでも高くすれば蒸発潜熱も小さくなり，かつ，サ イクル効率もより高くなって動力転換量が多くなるが, 蒸発温度は熱源温度以上に高くできないし，あえて高く すれば，蒸発潜熱が大きいことが原因して熱源の温度降 下を小さくすることになり，熱エネルギの回収量が少な くなる (6図参照).中・低温廃熱に対して蒸気サイクルで 動力を回収しようとすると，回収熱量を多くしようとす れば蒸気圧力が低くなって回収熱量当りの転換動力が減

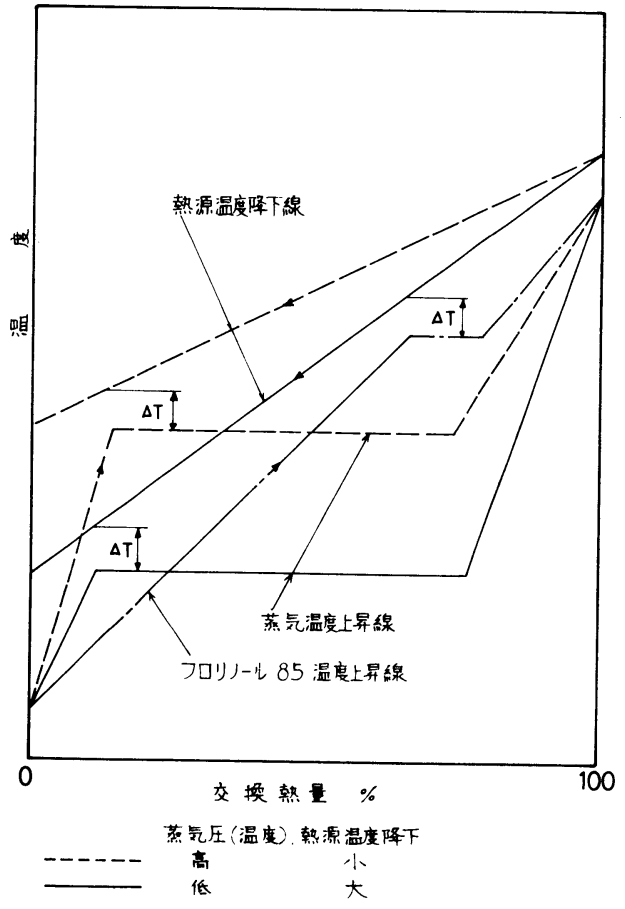

図 6 作動媒体温度上昇線図

り，蒸気圧力を高くして回収熱量当りの動力を増そうと すると回収熱量そのものが隇少する. いずれにしても, 廃熱量に対する回収動力を增そうとすると蒸気以外の媒 体が必要とされる.

4.2 フロリノール85 米国サーモェレクトロン 社(Thermo Electron Corporation)では蒸気以外の媒 体を使うことで動力回収の効率を上げようと，既に過去 10 年余りにわたって研究を継続してきており, 数百種類 の媒体の実験の結果, フロリノール85なる低沸点有機物 質が蒸気が慣用されてきた温度に次ぐ中·低温領域 $(200$ $\left.\sim 500^{\circ} \mathrm{C}\right)$ の熱源の動力転換に対して極めて良好なる成績 を示すことを確認し，このフロリノール85なる有機物質 を熱媒体としたオーガニックランキンサイクルシステム (ORCS) を開発している. 当社でもこの媒体の有用性に 着目し, 昨秋上記サーモェレクトロン社よりORCSの基 本技術を導入し当社の技術を付加することにより，省エ ネルギシステムを開発，実現することにした。フロリ， ール 85 の物性を下記する.
組 成 $\mathrm{CF}_{3} \mathrm{CH}_{2} \mathrm{OH} 85$ モル\% $+\mathrm{H}_{2} \mathrm{O} 15$ モル\%
分子量 87.74
比重 1.25
沸点 $76.1^{\circ} \mathrm{C}$
凝 固 点 $-63.3^{\circ} \mathrm{C}$
燃焼性 不燃性, それ自体では燃焼は持続しない.
熱安定性 $600^{\circ} \mathrm{F}\left(315.6^{\circ} \mathrm{C}\right)$ まで実機テスト済 $650^{\circ} \mathrm{F}\left(343.3^{\circ} \mathrm{C}\right)$ までカプセルテスト済 
毒性なし. Manufacturing Chemist Associationの無毒性規準を満足している.

腐 食性 水に比し極めて軽微

図 6 に示すようにフロリノール 85 では, 蒸気では困 難であった 2 要件が活立でき, 蒸発潜熱が小さいため熱 源温度降下を大きくとれると同時に, 受熱状態線図が熱 源温度降下線に十分近接していること, また, 高温, 高圧 の蒸気が発生出来るので動力回収量が大きくとれること となる.

4.3 その他の媒体 今までにフロリノール85は $200 \sim 500{ }^{\circ} \mathrm{C}$ の . 低温度の熱を動力に変えるのに優れ た媒体であることを示してきた.これはフロリノールの 熱力学的性質がランキンサイクル媒体として，この中. 低温度域に最も相性が良いことを意味するものである. 有機物質は一般に熱安定性の面で高温度限界があり, 熱 源盜度が高い場合でも, 水蒸気のごとくそれに応じて高 盜, 高生に指向できず, サイクル最高温度は熱安定限界 に押える必要がある. したがって, フロリノール 85 にあ っても $500^{\circ} \mathrm{C}$ 以上の高温熱源では蒸発器での非可逆性が 大きくなり, 水蒸気に対する優位性が次第に薄れていく ことになる. 熱安定性限界温度は一般に媒体沸点が高い ほど高く，低いものほど低くなる傾向にある，一方，熱 源温度が低くなれば, その温度低下に応じて高温, 高圧 の蒸気が次第に得られなくなり, フロリノール85よりも さらに，低い沸点を有する他媒体の出番となるであろう. 代表的なものとして, フロン 11 (沸点 $23.8^{\circ} \mathrm{C}$ ), および ペンタン $\left(36^{\circ} \mathrm{C}\right)$ がある.

\section{ORCS の適用例}

フロリノール 85 を使用したORCSは, 陸舶用ディー ゼルエンジン, ガスタービンの排ガス等の中・低温度レ ベルの廃熱を動力に回収転換する分野に幅広く適用が可

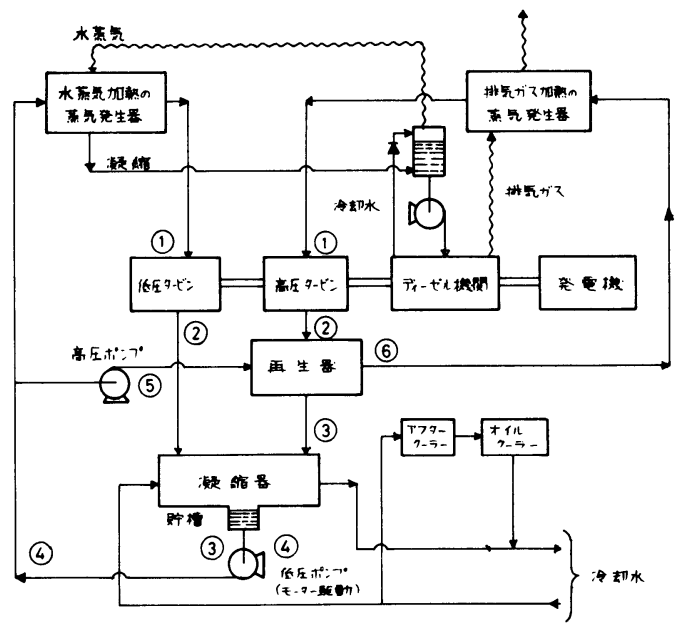

図 7 ディーゼル/ORCS 複合サイクル ブロックダイグラム
能である. 図 7 に 2.2 に示す複合サイクルのフローダイ ヤグラムを示す. 以下にその高圧ランキンサイクルの特 性を示す.

\begin{tabular}{|c|c|}
\hline 作動媒体 & フロリノール 85 \\
\hline \multicolumn{2}{|l|}{ 蒸気発生器 } \\
\hline 出口圧力 & 49.2 ata \\
\hline 出口温度 & $315^{\circ} \mathrm{C}$ \\
\hline 受熱量 (全熱) & $159.4 \mathrm{kcal} / \mathrm{kg}$ \\
\hline 受熱量（顕熱） & $84.7 \mathrm{kcal} / \mathrm{kg}$ \\
\hline 受熱量 (蒸発) & $23.1 \mathrm{kcal} / \mathrm{kg}$ \\
\hline 受熱量（過熱） & $51.6 \mathrm{kcal} / \mathrm{kg}$ \\
\hline \multicolumn{2}{|l|}{ タービン } \\
\hline 軸効率 & 0.808 \\
\hline 軸出力 & $46.7 \mathrm{kcal} / \mathrm{kg}$ \\
\hline 排気温度 & $143.5{ }^{\circ} \mathrm{C}$ \\
\hline 排気圧力 & 0.181 ata \\
\hline \multicolumn{2}{|l|}{ 再生器 } \\
\hline 効率 & 0.90 \\
\hline 交換熱量 & $29.3 \mathrm{kcal} / \mathrm{kg}$ \\
\hline 蒸気出口温度 & $44.9^{\circ} \mathrm{C}$ \\
\hline 給液出口温度 & $102.9^{\circ} \mathrm{C}$ \\
\hline \multicolumn{2}{|l|}{ 凝縮器 } \\
\hline 器内圧力 & 0.162 ata \\
\hline 凝縮温度 & $32.2^{\circ} \mathrm{C}$ \\
\hline 交換熱量 & $111.6 \mathrm{kcal} / \mathrm{kg}$ \\
\hline \multicolumn{2}{|l|}{ 給液ポンプ } \\
\hline 効率 & 0.7 \\
\hline 仕事量 & $1.38 \mathrm{kcal} / \mathrm{kg}$ (軸駆動) \\
\hline 正味軸出力 & $45.3 \mathrm{kcal} / \mathrm{kg}$ \\
\hline サイクル効率 & $28.4 \%$ \\
\hline
\end{tabular}

\section{ORCS の特長}

フロリノール 85 ランキンサイクルの蒸気サイクルに対 する主要特長を次に示す.

（1）高い動力回収ができる. 同一廃熱源温度に対し, $250 \sim 500^{\circ} \mathrm{C}$ 温度範囲で出力比 $10 \sim 30 \%$ 以上が期 待出来る. 図 8 に両者の出力対比を示す.

（2）蒸発器が貫流式に適する. 密閉循環サイクルであ ることに加えて, 臨界状態近くの高圧であり, また, フロリノール 85 が水に比し腐食性が極めて微弱であ ることより蒸発器が貫流式に適する.

（3）タービンが小形に出来る.

1) 同じ熱量回収では蒸気タービンに比べて容積流量 がタービン入口，出口とも小さい．

2) 湿り域での膨張がなく終段およびその近傍での翼 面ドレンアタックが避けられる．翼面ステライト盛 り，およびヶーシングドレン抜き穴等の湿り対策を 必要としない.

（4）タービン回転数を小さくすることができる. 同一 段数, 同一効率とした場合, 蒸気タービンに比べて 


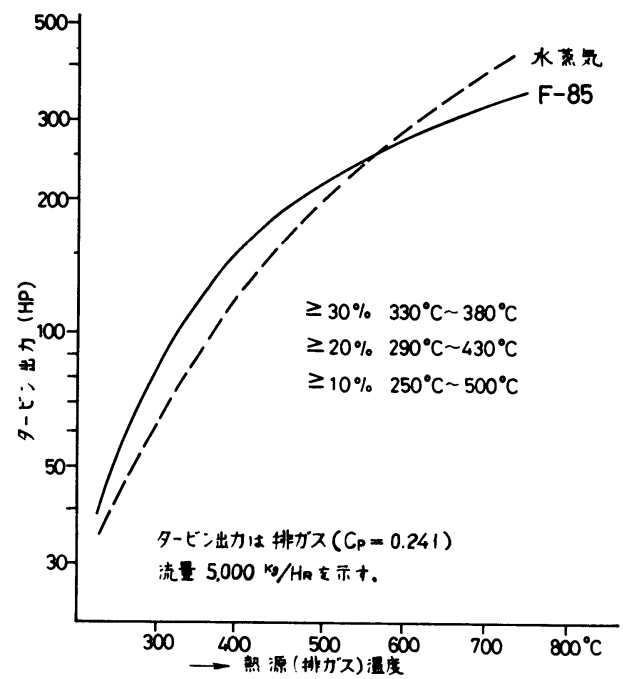

図 $8 \mathrm{~F}-85 /$ 蒸気出力比

回転数が小さいので安全性が高い

（5）再生器で給液が予熱できる. 膨張後の過熱蒸気で 給液加熱が出来るので効率が上がり(蒸気サイクル の給水加熱ではタービン抽気を使用)かつ，蒸気発 生器で低温腐食が回避出来る.

\section{7. 舶用原動所への有用性}

排ガスエコノマイザによるターボ発電機駆動は大出力 ディーゼル主機では既に慣用されている技術である.

しかし, 主機出力が $15,000 \mathrm{ps}$ 程度になると排ガスエ コノマイザでは船内電力をまかない得る容量のターボ発 電機を駆動するに十分な蒸気が得られないこと，および ターボとディーゼル発電機との並列運転は一般にわずら わしいことでもあって,これら中・低出力ディーゼル主 機とう載船では, 現在まではターボ発電機を装備せずデ ィーゼル発電機のみが装備されているのが実情である.

蒸気に代る ORCS では, 蒸気サイクルに比し出力が 10 〜30\%程度多く得られるので, 従来ターボ発電機装備が 無理視されてきた中出力ディーゼル主機とう載のバルク キャリヤー, ライパーにも，主機排ガスを利用するORCS 発電機を装備できる可能性が拡大されることとなる.

図 9 にディーゼル主機排ガス保有熱量と, 船内必要熱 量のバランスを示す. 主機は三井 B \& Wであり, 船内必要 熱量とは, 船内電力をまかない得る容量のターボ発電機の 駆動所要蒸気 (水蒸気または F-85 蒸気) および船内雑用 水蒸気を発生するのに必要な合計熱量を意味する.この 熱量バランスのみから見た場合, 通常航海時の電力量べー スで, 蒸気駆動ターボ発電機にあっては $18,000 〜 13,500$ ps が装備限界であるが，ORCSにあっては13,500〜 $10,000 \mathrm{ps}$ 程度まで装備限界が扗大されることとなる.

一方, 見方を変えて, 船内必要電力は従来通りディー

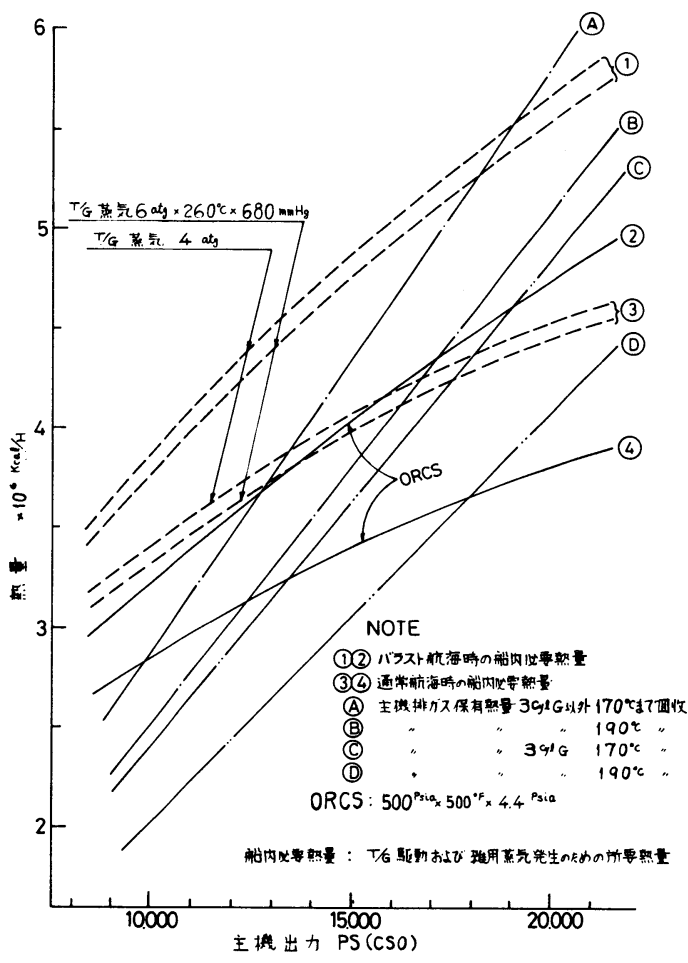

図 9 主機排ガス保有熱量と船内必要熱量

ゼル発電機でまかなうとして, 船内雑用蒸気女発生せし めてもなお余りある主機ディーゼルの排ガス保有熱量を 回収してORCSを組み, そのタービン出力を推進動力に 利用する方法も考えられる. また, 主機が大出力になる につれて, その排ガス保有熱量は, 従来形の蒸気タ一ボ 発電機を駆動したときでもなお余㮃の傾向であるので, この余劋分はORCSで推進に利用できよう. 主機ディー ゼルのみならず, 補機ディーゼルあるいは将来装備が話 題となるガスタービン主機の排ガスも ORCSによる回収 対象となるが, タービン船の主ボイラ排ガスは既に低温 域まで利用しているので, 現状では回収対象とはなり得 ないであろう.

\section{8. 舶用としてのORCSの今後の課題}

舶用ディーゼル機関は現在でも最も高温の廃熱を多量 に排出している熱機関の一つであり，蒸気に代ってフロ リノール 85 を媒体とする ORCS は, 廃熱を電力や推進 動力へ回収転換するのに有用な手段であると言えよう.

しかし, 実用化に祭してはいろいろの問題が介在する. 廃熱回収装置にあっては, その構成機器が大形化の方 向にある. 特に蒸気発生器では, 廃熱回収程度を大きく するほど温度差が小さくなり必然的に伝熱面積が増し大 きなものとなり価格高にもなる．機関室スペースは現在 すでに極度に切りつめられた空間であり，また，廃熱回 
収を理由に機関室スペースの延長も一般に許されないの で，いかに小形化するかが課題であろう．蒸気発生器に あっては貫流形にしてドラムを排除すること, 凝縮器お よび再生器にフイン付き伝熱管を使用するのもその対処 策の一つである.

有機物質を作動媒体として船内最重要補機であるター ボ発電機を駆動することは現在まで全く前例がない.そ れぞれの船級協会のご指導を仰ぐべき項目である.

フロリノール 85 は現在国産化して抢らず，輸入に仰ぐ ので高価格であり，この意味で軸封および管系漏れには 十分なる対策が要求される.

発電機駆動に利用する場合は, 船内電力安定確保の見 地から主機ディーゼル出力変動, 電力負荷变動に対処し 得る制御を慎重に配虑する必要がある.

廃熱保有熱量の回収度向上は蒸気発生器の低温腐食対 策を必要とする. 安価な耐食性材料の実用化が期待され るところである.

\section{9.むすび}

廃熱エネルギのなかでもェネルギ価值が比較的高い中 温度領域 $\left(200 \sim 500^{\circ} \mathrm{C}\right.$ )を高効率で最も利用価値の高い 電力あるいは動力への回収転換を可能とする ORCS の意 義は極めて大きい，従来より回収の意志が十分あったに もかかわらず蒸気に代る有用な媒体がなく, 止むを得ず 放置されていたものであり，フロリノール85 サイクルの 高効率性を活用することで, 舶陸両分野にわたって省エ ネルギが一層推進されることであろう.

当社では, 昨秋米国サーモエレクトロン社より, フロリ ノールを媒体とするORCSの基本技術を導入し, 現在, 陸上産業プラントの廃熱回収を対象に $500 \mathrm{kw}$ 容量の廃熱 回収発電装置の一号機を開発中であり, 近い将来に細部 にわたって詳述する機会があることをのぞむ次第である.

\section{文献}

1) Dean T. Morgan \& Jerry P. Davis, TECO Report No. TE418627-75, Nov. 1974

2）一色, 日本鉄鋼協会第 39 回記念技術講座，5，1976 